Hydropower converters with head differences below $2.5 \mathrm{~m}$

Bozhinova Hecht, Kisliakov, Müller and Schneider http://dx.doi.org/10.1680/ener.11.00037

Paper 1100037

Received 21/10/2011

Accepted 18/10/2012

\title{
Hydropower converters with head differences below 2.5 m
}

Snezhana Bozhinova Dipl-Ing

Research Assistant, University of Architecture, Civil Engineering and Geodesy, Sofia, Bulgaria

Veronika Hecht Dipl-Ing

Research Assistant, Technische Universität Darmstadt, Institute of Hydraulic and Water Resources Research, Darmstadt, Germany

Dimitar Kisliakov Dr-Ing

Associate Professor, University of Architecture, Civil Engineering and

Geodesy, Sofia, Bulgaria
Gerald Müller Dipl-Ing, PhD

Senior Lecturer, University of Southampton, Faculty of Engineering and the Environment, Southampton, UK

Silke Schneider Dipl-Ing

Research Assistant, Technische Universität Darmstadt, Institute of Hydraulic and Water Resources Research, Darmstadt, Germany

Hydropower with very low head (VLH) differences constitutes a largely unused potential source of renewable energy. A literature review of hydropower converters for VLH differences covering the engineering literature from the 1830s onwards was conducted to assess the potential of historic, current and emerging technologies. The results showed that a large number of different interesting technologies were used/developed, and that several novel and promising concepts are currently under development. Technologies emerged for different market segments: water wheels for low flow rates, turbines for large flow volumes. To take account of increased ecological demands and the desire for cost reduction, further improvements of existing technologies and new converter technologies have been developed. Other concepts described in the literature were apparently never applied although they promise development potential. The information gathered allowed for a comparison of available technologies with respect to area of application, performance, ecological impact and cost level.

\section{Introduction}

Hydropower with very low head (VLH) differences between 0.5 and $2.5 \mathrm{~m}$ is an area of hydropower in which a significant, but unused, potential both in rivers and in irrigation systems is available. Currently, there seems to be no cost-effective and ecologically acceptable hydropower converter available for the exploitation of this resource. The large number of old and currently disused low head hydropower sites in Europe does, however, indicate that low head hydropower sites were considered viable in former times. The current situation in which there is a desire to develop all sources of renewable energy has attracted and still attracts a large number of researchers and inventors who try to overcome the technical difficulties connected with the exploitation of low head hydropower. Many concepts were developed, tried or even made operational, but have subsequently been forgotten. This may be owing to the fact that novel machines could not be developed further because the available materials or analysis techniques were not suitable, or because the necessity for the utilisation of smaller low head hydropower sources was not considered a priority as large centralised power production was the preferred development philosophy. Consequently, most of the small hydropower sites built in the second half of the nineteenth and the beginning of the twentieth century were taken out of operation in the 1950s and 1960s, and much of the technology developed was forgotten. There is now again a strong demand for the utilisation of low head hydropower. In order to first identify and then assess the value and possible development potential of reported technology, the engineering literature of the 1830 s to the 1980 s was searched and analysed. This seemed particularly interesting because modern materials and analysis methods are now available that may allow the use of concepts considered not usable a century ago. More importantly, modern design requirements not only focus on performance and economy, but also very strongly on ecological characteristics, such as fish and sediment passage. In this study, particular attention was paid to hydropower converters for head differences below $2 \mathrm{~m}$ because this was perceived to be an area in which existing technology meets its limits.

\section{Technologies with demonstrated performance}

\subsection{Introduction}

Hydropower with VLH differences has been utilised for centuries, for several reasons.

- The construction of dams and weirs for low head differences is simpler and less costly than larger dams.

- Mechanical power was very valuable, and even small head drops were therefore economical. 
- Small natural falls in low land river reaches can be exploited.

A number of different hydropower converters established themselves for this hydropower segment; the type of machine built depended on head difference and, more importantly, the flow volume. Water wheels were employed for small, turbines for larger volumes. Technologies with increasing efficiencies evolved with the development of hydraulic engineering as a scientific subject. The interest in the subject disappeared in the 1950 s to 1970 s, with centralised large power stations becoming the prevailing solution. In recent years, with growing interest in all renewable energy sources, VLH hydropower has become attractive again and some new developments have appeared, whereby the increasing ecological awareness has meant that design criteria focus not just on power output and costeffectiveness, but also on ecological performance. In the following section, hydropower converters that are currently available, those that were in widespread application but have mostly disappeared and two novel types for which performance data are available will be presented.

\subsection{Water wheels}

\subsubsection{The impulse wheel}

One of the earliest hydropower machines for the utilisation of VLH differences is the impulse wheel. Water is accelerated through a drop, and the fast supercritical flow drives the wheel. Figure 1(a) shows such a wheel with a $5.20 \mathrm{~m}$ diameter, a width of $3.65 \mathrm{~m}$, a water depth of $0.38 \mathrm{~m}$, a flow speed of 6 $7 \mathrm{~m} / \mathrm{s}$ and a power production of $33 \mathrm{~kW}$, giving an efficiency of only 0.18 . A theoretical analysis shows that $40 \%$ is the maximum possible efficiency. Tests conducted at the Technical University Berlin indicated efficiencies of 35-38\% (Figure 1(b)) (Müller et al., 2007).

Possible efficiencies therefore range from $35 \%$ to $40 \%$ for specific flow rates of $Q=1-3 \mathrm{~m}^{3} / \mathrm{s}$ per $1 \mathrm{~m}$ width and head differences (or drops) of 0.4-1.5 m.

\subsubsection{The Poncelet wheel}

The Poncelet wheel was developed in France in the 1820s in order to improve the efficiency of undershot wheels for VLH differences, and subsequently found widespread application. It consists of a wheel with deep curved blades and an inflow with an undershot weir. The water jet from the weir enters the wheel, exchanges its impulse, the water rises inside the wheel and then falls out, performing additional work. Theoretical analysis and experiments conducted by the inventor showed efficiencies of $55-65 \%$, whereby the efficiency reduces with increasing head difference. Head differences utilised ranged from 0.75 to approximately $1.7 \mathrm{~m}$, and efficiencies were assumed as $60-65 \%$ for $0.75 \leq H \leq 1.2 \mathrm{~m}$, and $55-60 \%$ for head differences between 1.2 and $1.7 \mathrm{~m}$. As Poncelet's second
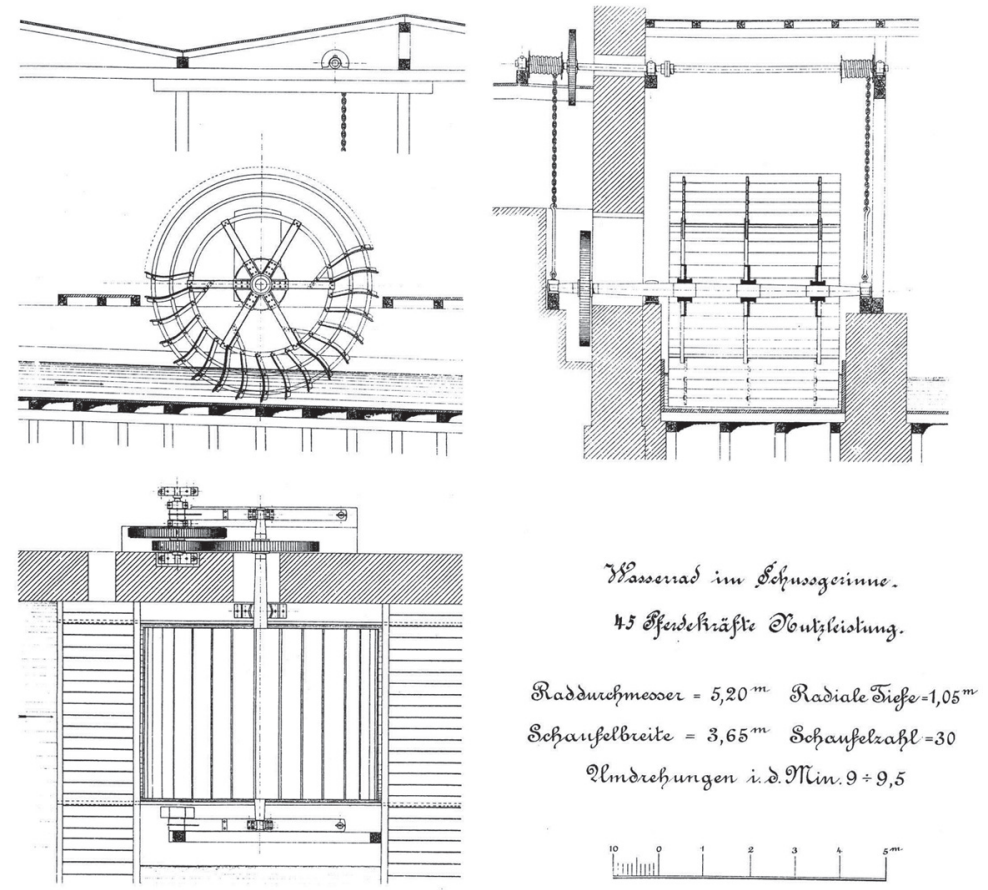

(a)
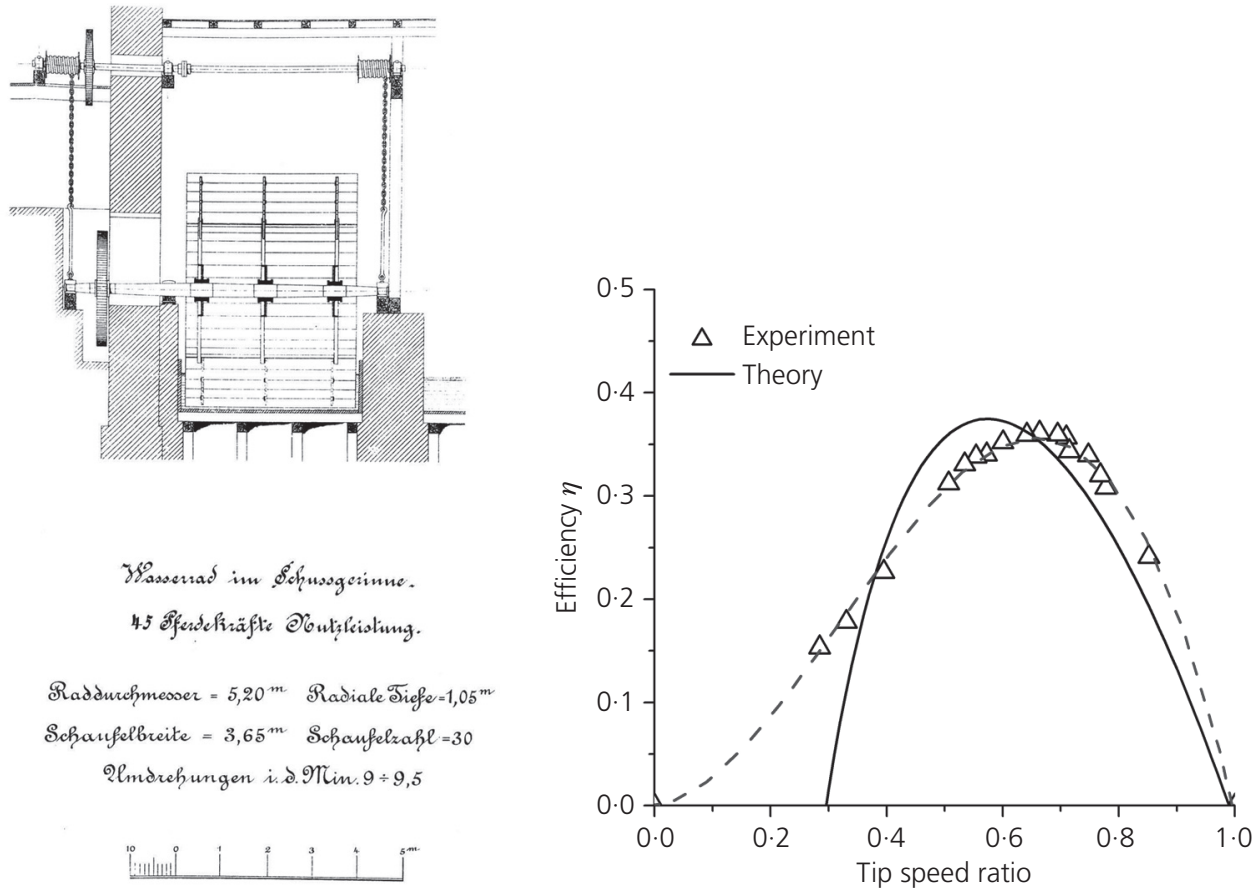

(b)

Figure 1. Impulse wheel in supercritical flow. (a) Impulse wheel, $D=5.2 \mathrm{~m}, P=33 \mathrm{~kW}$ (Müller, 1899); (b) efficiency 


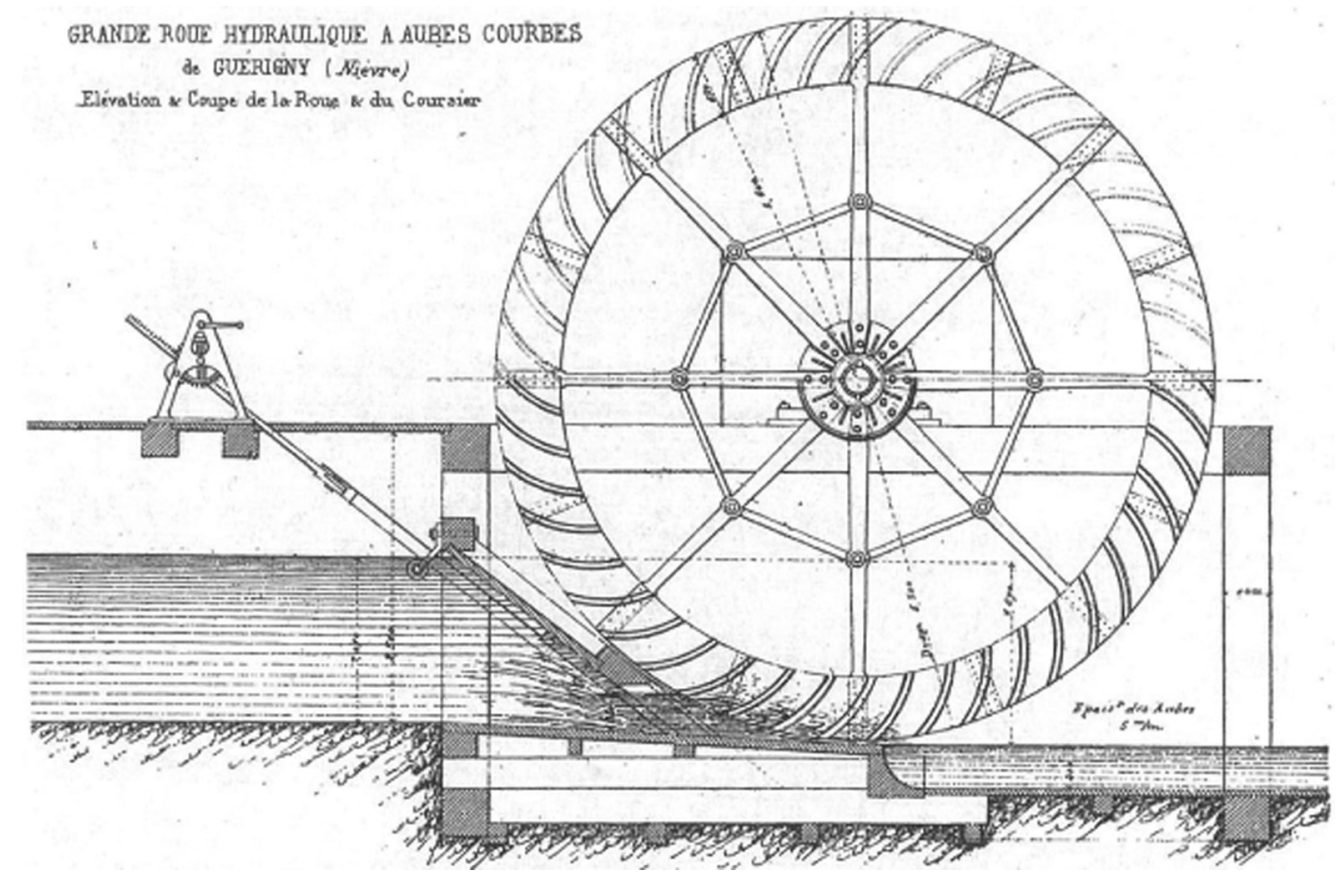

Figure 2. Poncelet wheel (Poncelet, 1827)

series of tests did not really confirm the higher efficiency of $65 \%$, a maximum mechanical efficiency of $60 \%$ is usually assumed (e.g. Müller, 1899). Flow rates ranged from $Q=0.3$ to $1.5 \mathrm{~m}^{3} / \mathrm{s}$ and $\mathrm{m}$ width, with power outputs of $P=1$ to $13.8 \mathrm{~kW} / \mathrm{m}$ width. Typical diameters were 3-6 m, (Poncelet, 1827; Weisbach, 1883). Figure 2 shows a side elevation of a typical Poncelet wheel.

Poncelet wheels are occasionally built again now, although, to our knowledge no theoretical or experimental work on theory or performance has been reported. It should be mentioned that in the late nineteenth century, Poncelet wheels were perceived to be damaging to fish, contrary to other water wheel types, which was probably owing to the very fast jet flow and the pinching contact of the blade (Gerhardt, 1893).

\subsubsection{The Zuppinger wheel for VLH differences}

Zuppinger water wheels were developed for low head hydropower sites with head differences between 1.5 and $2.5 \mathrm{~m}$, and with power ratings between 5 and $100 \mathrm{~kW}$. They are characterised by curved blades, large diameters between 4.5 and $7.5 \mathrm{~m}$, and a slow rotational speed of 4-6 rpm. The inflow was regulated with a weir, so that the upstream water level and the wheel speed were kept constant. In order to exploit head differences between 0.7 and $1.5 \mathrm{~m}$ a special wheel type was developed that did not have a weir inflow, as shown in Figure 3. The wheel maintains the head difference, which means that the wheel speed becomes a function of the flow volume. Efficiencies were given as $70-75 \%$, slightly lower than the standard Zuppinger wheels. No theory for this type of wheel was, however, developed. The specific flow volumes range from 1.0 to $1.2 \mathrm{~m}^{3} / \mathrm{s}$ per $1 \mathrm{~m}$ width with power ratings from 5.3 to $12.8 \mathrm{~kW} /(\mathrm{m}$ width).

While standard Zuppinger wheels are still (or rather, again) built, the VLH wheel has, to our knowledge, not seen any recent application. In principle, it is similar to the recently developed hydrostatic pressure wheel (HPW) (Senior et al.,

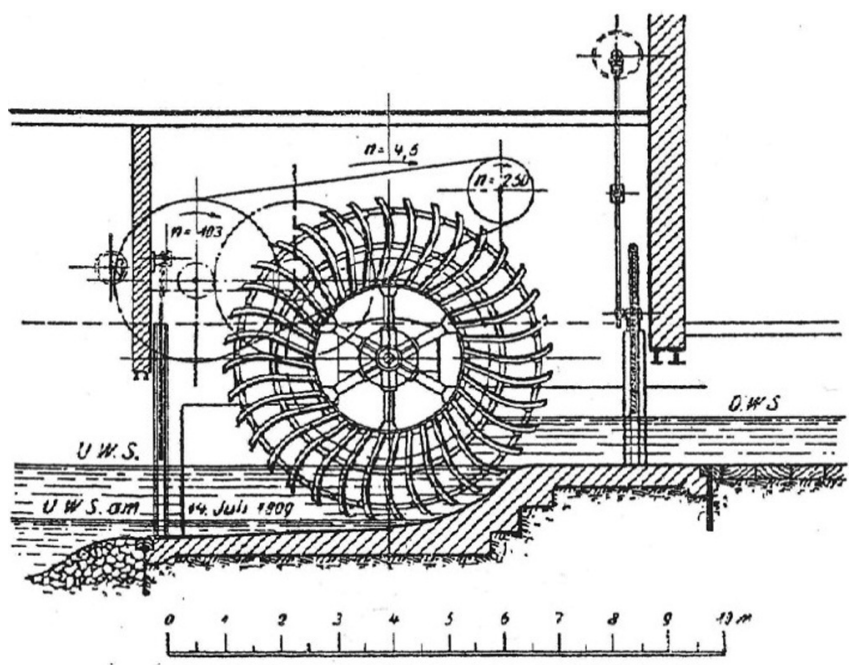

Figure 3. Very low head Zuppinger wheel without regulating inflow weir (Müller, 1899) 


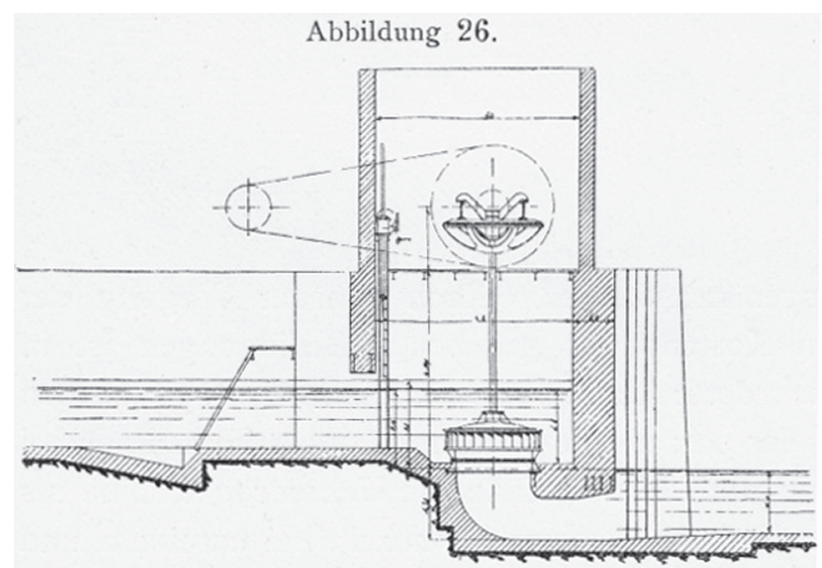

Francisturbine mit stehender Welle im offenen Schacht. (G. Luther, Braunschweig.)

(a)

Figure 4. Low head Francis turbine. (a) Vertical turbine, $H=1.40$ m (Graf, 1906); (b) siphon turbine (Ludin, 1913)

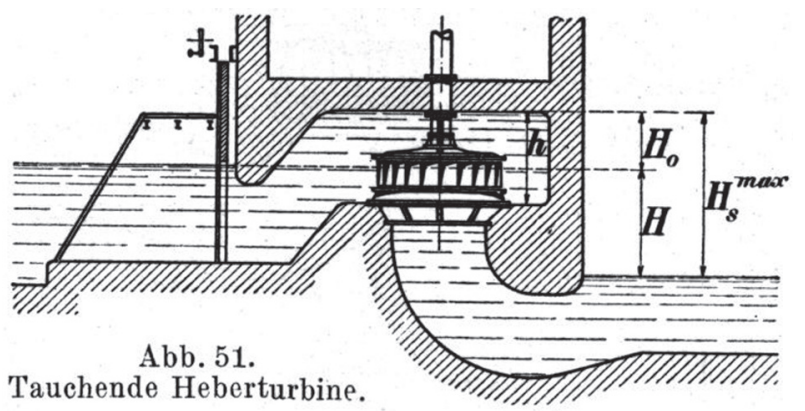

(b)
2010). Its disadvantages are the large number of blades (and subsequent costs) and the negative effect of buoyancy forces of the $50 \mathrm{~mm}$ thick wooden blades, which reduce efficiencies by 6-8\% (Schneider et al., 2009). Advantages are the higher theoretical efficiency as a function of the high number of blades, the perceived fish friendliness (Gerhardt, 1893) and the possibility of sediment passing through. Experimental assessment is, however, considered necessary to provide reliable data for performance prediction.

\subsection{Reaction turbines}

\subsubsection{Francis turbines}

In the late nineteenth and early twentieth century, Francis turbines were used for head differences from $0.75 \mathrm{~m}$ onwards. For head differences between 0.75 and $5.0 \mathrm{~m}$, they were built in open arrangements with a vertical shaft. Efficiencies ranged from $75 \%$ to $85 \%$, with a marked drop below $Q=Q_{\max } / 3$. Figure 4(a) shows such an installation for a head difference of $1.40 \mathrm{~m}$ and a power rating of $25 \mathrm{~kW}$. Diameters were naturally quite large for low head differences; a $25 \mathrm{~kW}$ turbine had a diameter of $1.2 \mathrm{~m}$ (Ludin, 1913).

The problem with a comparatively low part load performance was usually compensated by building power stations with multiple turbines.

Figure 4(b) shows a Francis siphon-turbine, a type of turbine built for VLH differences between 1 and $5 \mathrm{~m}$. The location of the turbine near, or even above, the upstream water level means that construction works below the water level are reduced, and that maintenance is easier.

\subsubsection{Kaplan turbines}

Kaplan turbines are propeller turbines with variable pitch blades and, as double-regulated turbines, also with variable inflow guide vanes. Kaplan turbines were built from the late 1920 s onwards. Low head applications range from 1.8 to $5.0 \mathrm{~m}$ head difference. For optimum efficiency, the turbine systems require not only the turbine itself but also an inflow structure, which minimises inflow losses and an outflow structure - the suction or draft tube, which decelerates the flow velocity and thereby recovers pressure head. Kaplan installations for VLH differences were frequently built in the 1950s and 1960s. Figure 5(a) shows such a power station for a head difference of $1.89 \mathrm{~m}$ and a flow volume of $4.5 \mathrm{~m}^{3} / \mathrm{s}$. The mechanical efficiency is given as $82 \%$ for a $1.89 \mathrm{~m}$ head (Rauch, 1959), with an overall efficiency of 60-70\%. Kaplan turbines are now offered for head differences from $1 \mathrm{~m}$ onwards with power ratings of $10-1800 \mathrm{~kW}$. These modern Kaplan turbines have efficiencies of $75 \%$ for $Q / Q_{\max }=0.2$ to $92 \%$ for $0.45 \leq Q / Q_{\max } \leq 1$, see Figure 5(b) (adapted from Ossberger, 2011). Compared with Francis turbines, Kaplan turbines have a slightly higher peak efficiency and a significantly increased part load performance. Despite this fact it is argued that owing to the high costs for the double-regulated turbine, and, in particular, the associated civil engineering works (inflow and draft tube), even the retrofitting of existing VLH Francis turbine installations with Kaplan turbines is in most cases not cost effective (Giesecke and Jorde, 1999).

Nevertheless, many compact application concepts of the Kaplan turbine have been developed in past decades. Such are the bulb unit, the pit turbine, the compact Kaplan turbine, the compact axial turbine, the S-turbine and some variations 


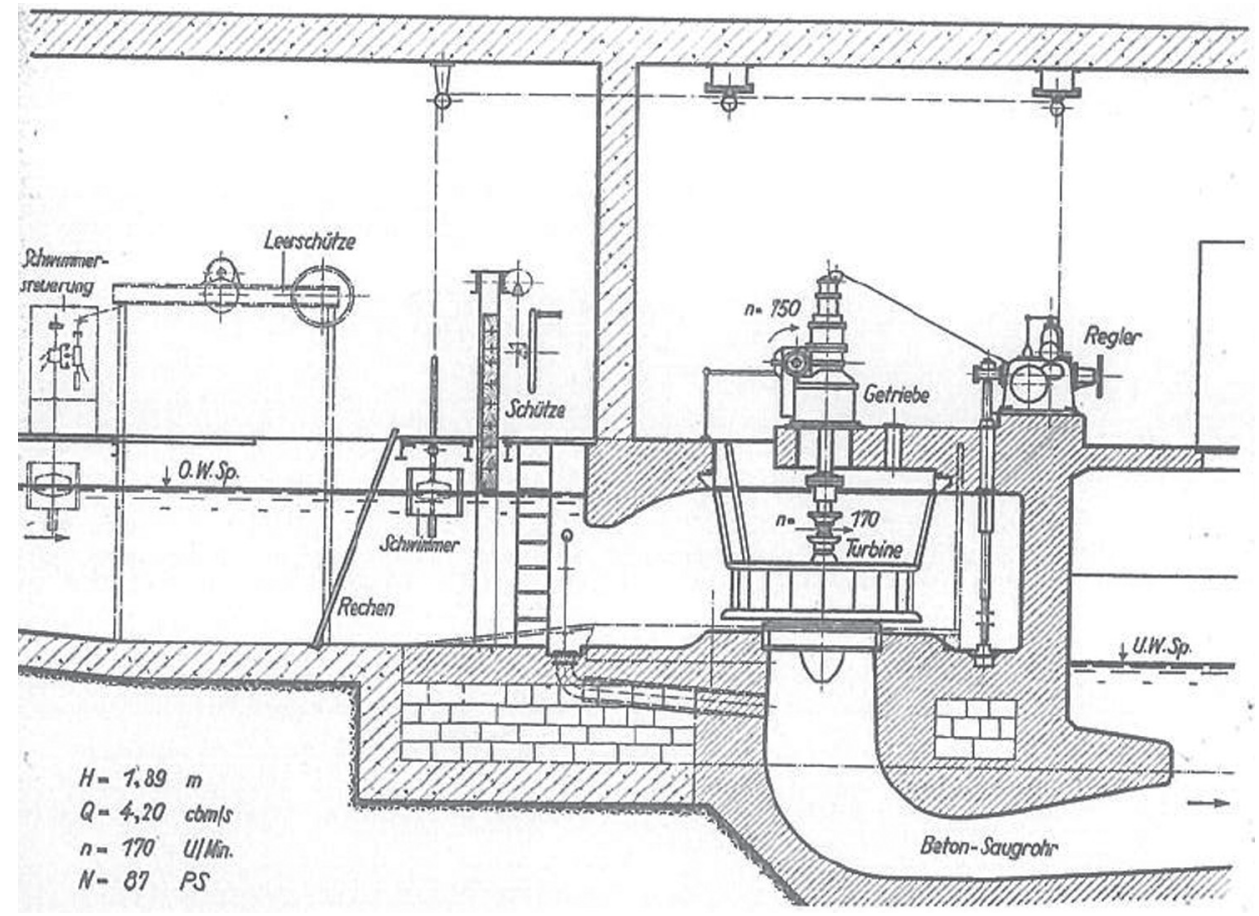

(a)

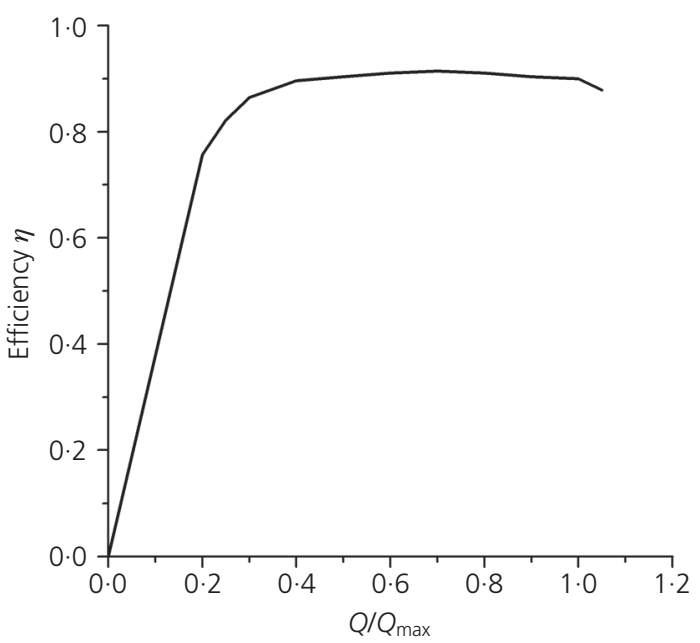

(b)

Figure 5. Kaplan turbines for very low head differences.

(a) Low head power station, $H=1.89$ m (Rauch, 1959; courtesy of

Kosmos Verlag); (b) efficiency of double-regulated Kaplan turbine

of these solutions. The aim of these developments was to enable the application of double-regulated turbines also for small hydropower projects, as well as to provide more efficient solutions for large run-off-river and tidal power plants. In some of these modern unit concepts, as for example HYDROMATRIX, only simply regulated turbines are implemented when this significant simplification is compensated by the number of installed units (Giesecke and Mosonyi, 2009).
However, as has been proved by numerous projects, all aforementioned developments could hardly be feasible in the VLH range below $2.5 \mathrm{~m}$ owing to the specific features and limits of the implemented turbine technology.

\subsubsection{The VLH turbine}

The VLH turbine is a recent development and combines a regulated propeller turbine with an in-built generator inside a 


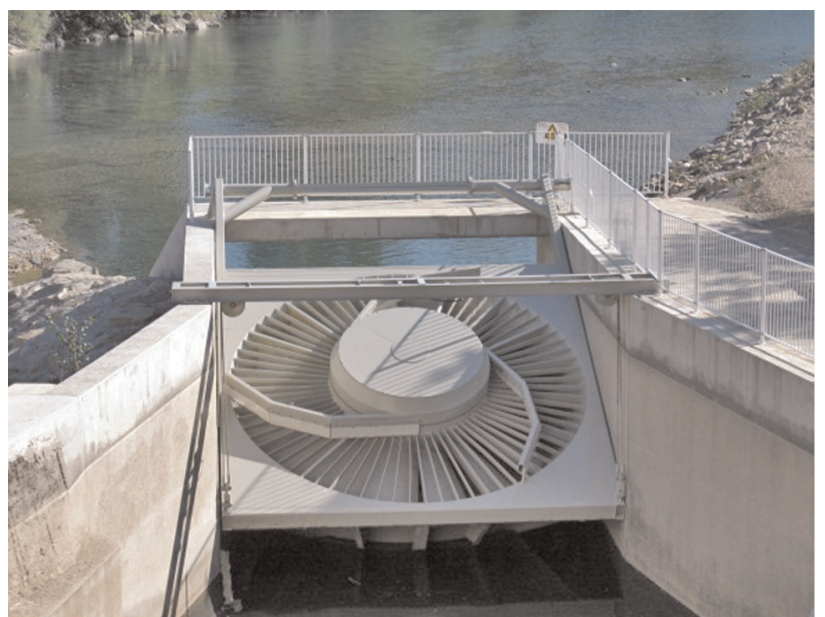

(a)

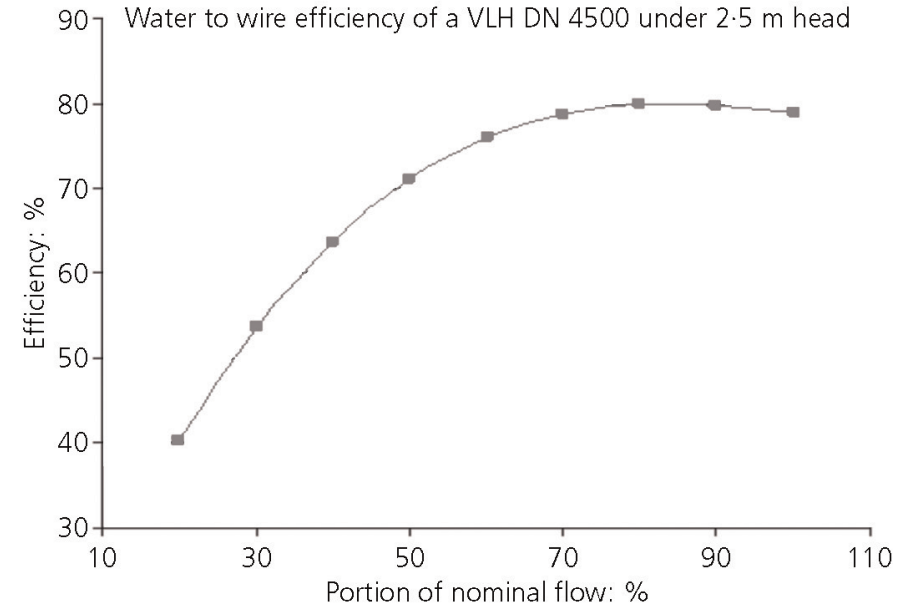

(b)

Figure 6. The very low head (VLH) turbine (M. Leclerc, 2011, with permission). (a) Downstream view; (b) full-scale efficiencies hydraulic to electric

movable housing and a trash removal screen (MJ2 Technologies, 2011). The simple geometry of the unit requires only a square concrete channel for mounting and can be raised or removed for maintenance or repairs (Figure 6(a)). The VLH turbine was developed for head differences between 1.4 and $3.2 \mathrm{~m}$, flow rates of $10-30 \mathrm{~m}^{3} / \mathrm{s}$ with a $3 \cdot 15-5.0 \mathrm{~m}$ diameter and power ratings from 100 to $500 \mathrm{~kW}$ (electrical power output).

The performance of the VLH turbine was determined experimentally, with a $672 \mathrm{~mm}$ diameter runner in which a maximum efficiency of $86 \%$ was obtained (Fraser et al., 2007). Full-scale measurements conducted on a $4.5 \mathrm{~m}$ diameter turbine showed hydraulic to electric efficiencies of $80 \%$, indicating that small-scale tests suffer from scale effects that generate additional losses (M. Leclerc, 2011, personal communication). In Figure 6(b) it can be seen that owing to its variable speed operation the VLH turbine has a good performance in the medium flow range $0.4<Q / Q_{\max }<1$, but that efficiencies drop below 0.6 for part load situations with $Q<1 / 3 Q_{\max }$.

Detailed tests were reported on the fish friendliness of the turbine. The average survival rate was established as $92 \%$. The mortality is 3-5 times lower than that of conventional turbines. It should be noted that the VLH turbine has an automated trash removal screen integrated into the turbine assembly. In May 2010, 16 installations with a total of 4.99 MW had been built.

\subsection{Potential/hydrostatic and other converters}

\subsubsection{The Archimedes screw}

The Archimedes screw is one of the two oldest hydraulic machines known to man. It was employed as a pump, but the French engineer Navier already mentioned the possibility of employing it in a power generation role at the beginning of the nineteenth century. The first tests of the Archimedes screw hydropower machine were, however, reported only recently (Brada, 1999). Figure 7(a) shows a typical power generation unit, with the screw running in a metal trough. The experimental results shown in Figure 7(b) were measured on a $30^{\circ}$ inclined screw with three turns and gave efficiencies of $80 \%$. Another test with the same angle resulted in efficiencies of $84.5 \%$ (Hellmann, 2003). In these tests the difference in energy lines assuming a theoretical outflow velocity was used to determine efficiencies; when using the water level differences the efficiency is again $80 \%$. The manufacturer claims efficiencies of up to $90 \%$ for all screws. Very recently, the first theory of the Archimedes screw was developed (Müller and Senior, 2009) (Figure 7(b)). The theory indicates that the maximum possible efficiency is a function of the geometry, efficiencies reduce with steeper angles and with wider turns (i.e. with increasing head difference between neighbouring cells). In general, it can be concluded that maximum efficiencies can reach approximately $80 \%$ for standard geometries and $30^{\circ}$ angles, steeper angles or simplified geometries lead to a reduction in efficiency.

The diameters of Archimedes screws range from 1.0 to $3.5 \mathrm{~m}$. It can be applied for head differences between 1.2 and $10.0 \mathrm{~m}$, flow volumes of $0 \cdot 3-6.0 \mathrm{~m}^{3}$ and power ratings between 3 and $300 \mathrm{~kW}$. All numbers appear to be based on efficiencies of $80 \%$; however, theory suggests that, in particular for large diameters in which head difference between neighbouring cells increase, this efficiency reduces. Figure 7 (b) also indicates the drop in performance for small flow rates $Q / Q_{\max }<0.3$. In a recent study, 36 efficiency measurements (hydraulic to electric) at 14 installed screws were reported (Lashofer et al., 2011). The average efficiencies were determined as $69 \%$, 


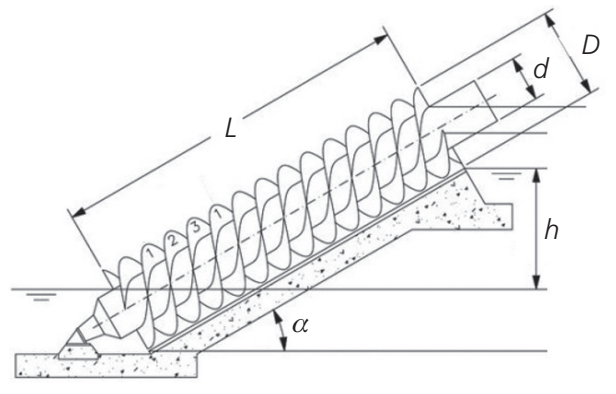

(a)

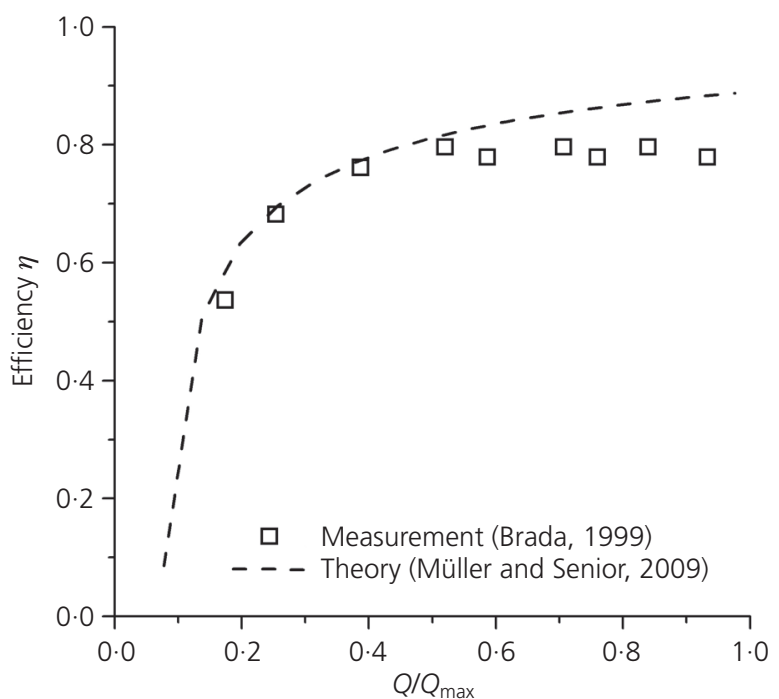

(b)

Figure 7. Archimedes screw. (a) Side view (Source: Wikimedia Commons, author: W. v. Braun); (b) experimental and theoretical efficiency

whereby some installations reached peak efficiencies of $75 \%$ (installations with variable speed operation). No information about the head differences of the measured installations was given. The head differences of all 71 catalogued screws reported in the study ranged from 1.0 to $6 \mathrm{~m}$, with a mean of $2.53 \mathrm{~m}$ so that it can be assumed that the head differences of the investigated machines was close to the upper limit of the area investigated in this paper. The fish friendliness of these machines was demonstrated in a number of studies in Germany and the UK (Fishtek, 2007, 2008; Späh, 2001).

\subsubsection{Hydrostatic pressure converters}

Two machines that employ hydrostatic pressure as the driving force for low head hydropower have been developed recently (Senior et al., 2010). Theoretical work indicated the potential of the concept, and small and large-scale model tests showed the possible conversion efficiencies. The HPW is a simple water wheel with radial straight blades, whereby the blades run in a curved bed section and hold the upstream water level; the wheel also acts as a weir (Figure 8(a)). Efficiencies are a function of the ratio of the down and upstream water level $d_{2} / d_{1}$. Theoretical and experimental efficiencies agreed well and reached from $60 \%$ to $90 \%$ for ratios of $0 \cdot 6 \leq d_{2} / d_{1} \leq 0 \cdot 9$. Initial assessments indicated that the HPW is suitable for head differences between 0.4 and $1.0 \mathrm{~m}$, with flow rates of $0.5-1.5 \mathrm{~m}^{3} / \mathrm{s}$ and $\mathrm{m}$ width giving power ratios from 2 to $12 \mathrm{~kW} / \mathrm{m}$ width.

The hydrostatic pressure machine (HPM) consists of a hub with a diameter approximately equal to the head difference, and blades that also run in a curved bed section. The upstream water level reaches the top of the hub, while the downstream level is located at its bottom (Figure $8(\mathrm{~b})$ ). The resulting hydrostatic force acting on the blade drives the machine. Efficiencies are a function of the wheel speed and reduce with increasing speed. In small- and large-scale experiments, efficiencies from $70 \%$ to $82 \%$ were measured for the operational range of speeds (Senior et al., 2010). Head differences range from 1 to $2.5 \mathrm{~m}$, flow rates from 1 to $3 \mathrm{~m}^{3} / \mathrm{s}$ and $\mathrm{m}$ width, and power ratings from 7 to $47 \mathrm{~kW} / \mathrm{m}$ width. Recent field measurements indicated overall efficiencies of 0.51 to 0.524 for $0.186 \leq Q_{\max } \leq 0.3$ and mechanical efficiencies between 0.74 and 0.85 .

Both machines are simple and therefore have the potential to be economical; the large cells and continuity of the bed imply improved ecological performance for both fish and sediment passage when compared with, in particular, the turbines described in section 2. Both machines are currently undergoing large-scale/full-scale testing.

\subsubsection{Gravitational vortex converter}

The gravitational vortex converter (GVC) consists of an inflow, a circular chamber with a central outflow and a simple vertical axis turbine, which is driven by the water's vortex flow (Figure 9). Head differences can vary between 0.5 and $2.5 \mathrm{~m}$, and flow rates between 0.5 and $20.0 \mathrm{~m}^{3} / \mathrm{s}$ (Zotlöterer, 2010).

The inventor claims efficiencies of $80 \%$ (Hahn, 2006). Recent tests in a Swiss University (Fachhochschule Nordwestschweiz) showed turbine efficiencies of $41 \%$ and an overall efficiency of $23.5 \%$ (Urbani, 2011). Further improvements are seen both in the area of power take-off (potential approximately 10\%) and turbine design. One particular advantage of the GVC is claimed 


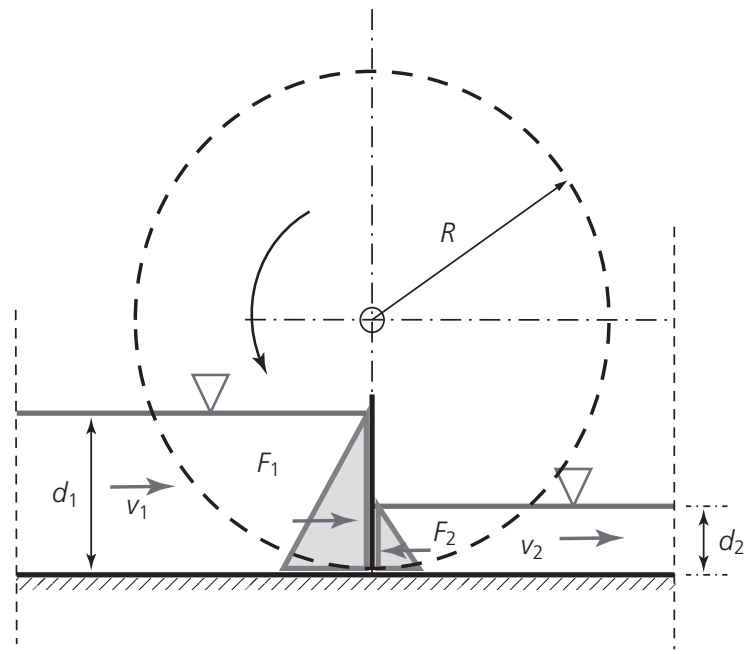

(a)

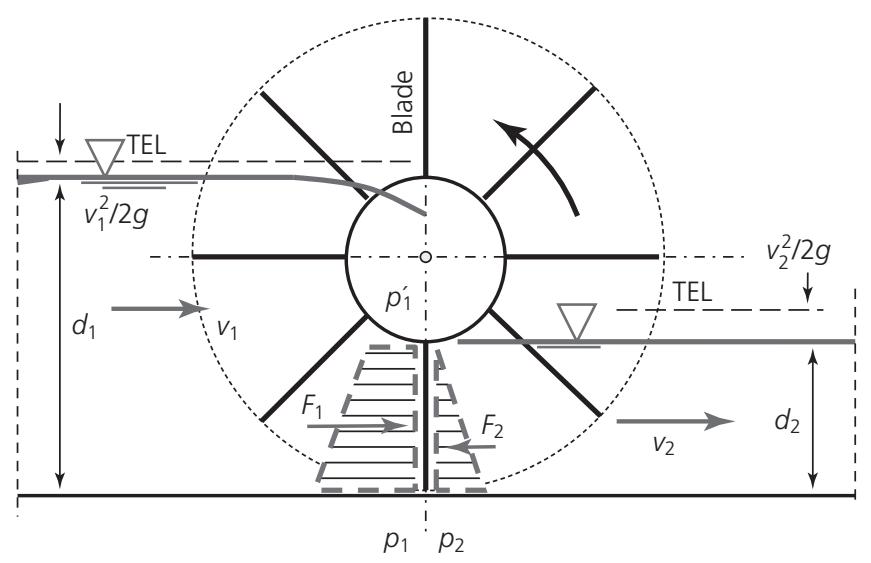

(b)

Figure 8. Hydrostatic pressure converters (adapted from Senior et al., 2010). (a) Hydrostatic pressure wheel; (b) hydrostatic pressure machine

to be the fish friendliness; fish can pass through the machine unhindered. A study of these characteristics is not available; the geometry of basin and turbine does, however, suggest that fish passage downstream is possible.

\section{Proposed/developing technologies and technologies with development potential}

\subsection{Introduction}

The development of cost-effective technologies for the exploitation of hydropower with VLH differences has attracted the attention of many researchers and inventors, and hundreds of patents have been granted. Most proposed machines are, how-

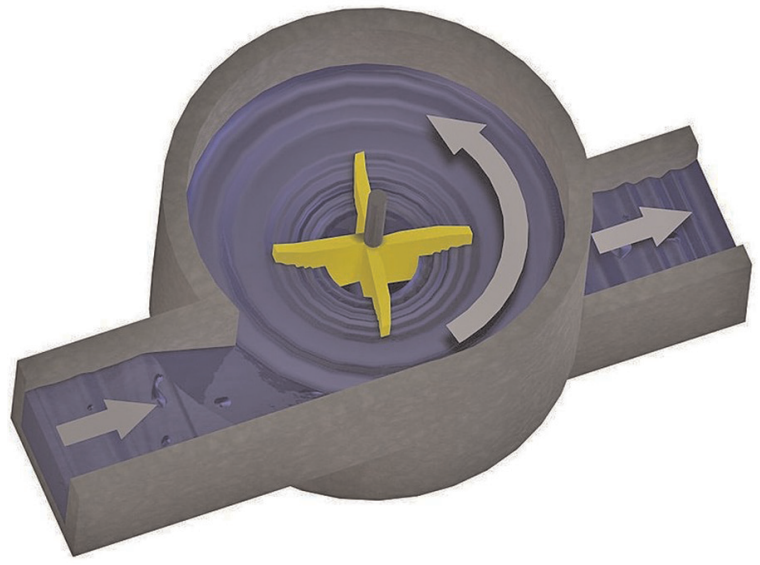

(a) ever, impractical or violate the laws of physics. The literature research did, however, reveal a number of interesting concepts that were suggested or built. A common feature of these conceptual machines is, however, that no detailed investigation of their performance and/or theoretical framework is currently available.

\subsection{Technologies}

\subsubsection{Zuppinger's wheel}

This wheel, also developed by the Swiss engineer, Walter Zuppinger, consists of a central hub, which also acts as a weir, and of curved blades somewhat similar to those of an

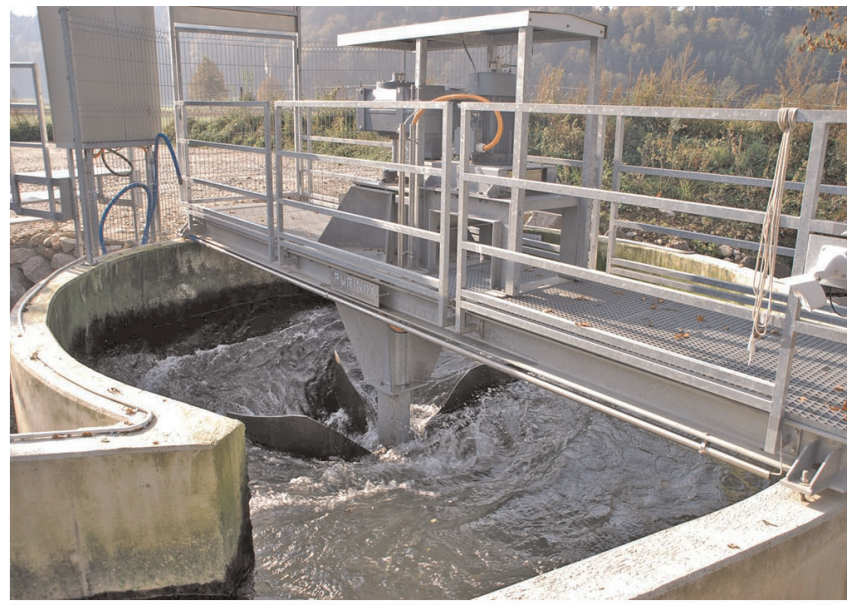

(b)

Figure 9. Gravitational vortex converter (with permission by GWWK Genossenschaft). (a) Principle; (b) $5.5 \mathrm{~m}$ dia. prototype ( $H=1.4 \mathrm{~m}$ ) 


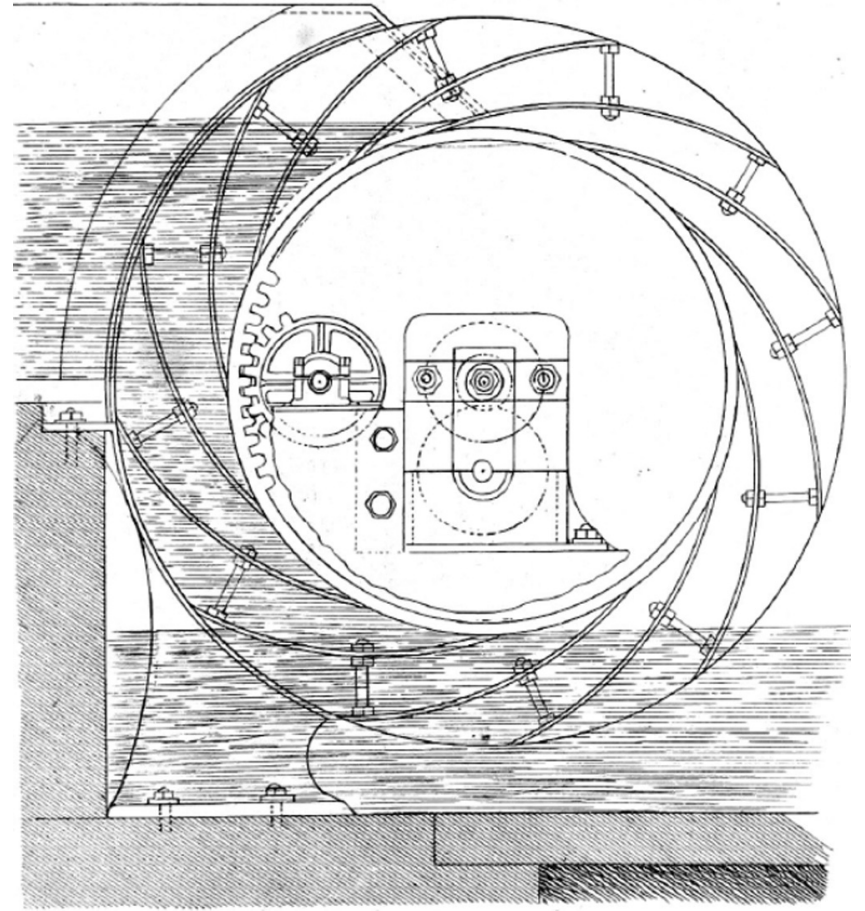

Figure 10. Zupppinger's water wheel from 1848 (Schnedermann and Böttcher, 1855)

overshot, or rather pitchback water wheel (Figure 10). The inflow upstream comes from both sides. The weight of the water drives the wheel, making it a potential machine. The outflow occurs within the downstream water level, so that 'the weight of the water in the cells is employed to the most perfect effect' (Weisbach, 1883). Efficiencies are given as 75-80\%, and very small head differences are seen as the area of application. A theory is mentioned in the literature, but was apparently never published.

No measurements, or indeed, actual constructions of such a wheel are reported. From a current point of view, this wheel, with its simple construction (without any components below the water level) and the possibility to process large volumes of water over an appreciable head difference, could be employed for head differences of $2-3 \mathrm{~m}$, that is at the lower limit of turbines and above the upper limits for the machines described in sections 2.1, 2.2 and 2.4.

\subsubsection{Chinese chain pump}

The Chinese chain or dragon spine pump consists of a rectangular channel, in which vertical blades connected with a driving chain are moving. The chain and blades run over two wheels that are fitted above the upstream and below the downstream end of the pump (Figure 11(a)). Although this simple hydraulic machine has been in use for nearly a thousand years, only one test is reported in the literature in which efficiencies of $40 \%$ in the pumping mode were measured (Collett, 1981). The functionality of the machine suggests that it could be employed to generate energy in the turbine mode; this does not seem to have been proposed so far. A brief look at the hydraulics of the Chinese chain pump shows that it is a hydrostatic pressure converter. The model developed for the Archimedes screw is directly applicable, giving theoretical efficiencies of $50-90 \%$ as a function of the ratio of head difference and water level in each cell - effectively a function of the angle and the number of blades (Figure 11(b)). Actual efficiencies in turbine mode should be higher than those observed for a pump.

\subsubsection{AUR water engine}

The AUR water engine, named after its inventor Alistair Ure Reid, is a hydropower converter that employs buoyancy forces. Two ballasted floating bodies are enclosed in two chambers, with gates opening towards the up- and the downstream. The buoyancy bodies are connected to hydraulic cylinders that act as power take-off. The chamber is flooded, producing an upward motion of the body. After reaching the upmost position, the upstream gate is closed, the downstream gate is opened during the evacuation of the chamber, the weight of the body becomes active, pulling the body down, generating pressurised flow in the hydraulic cylinders (Bassett, 1989).

Tests were conducted at Salford University using small- and large-scale models; the mean efficiency from the tests was given as 55\% (ETSU, 1989). Unfortunately, the inventors did not develop a theory for this device. This was done only recently (Müller et al., 2010) in the context of a similar wave energy device. The theory suggests that with the correct operating regime (i.e. with force and thereby elevation control), a theoretical efficiency of $100 \%$ can be reached, making this an interesting concept. The main disadvantages would be the large structure required, and the intermittent regime that inherently limits the volume flow through the installation and drives up costs per unit of power output. This intermittent operation does, however, make the concept interesting for applications in wave energy, in which the buoyancy is also intermittent (Müller et al., 2010).

\section{Discussion}

\subsection{Technology}

The wide variety of technologies available combined with the great interest in the field of hydropower with VLH differences, the number of hydropower converters that are available and, in frequent cases, the lack of technical information make it very difficult to establish an overview. In addition, some of the most important information - for example, about costs - is both difficult to get and very much time and location dependent. In order to get at least a start of an overview, we compiled Table 1, which lists the technical and ecological characteristics of those hydropower converters that are or were in use, and 


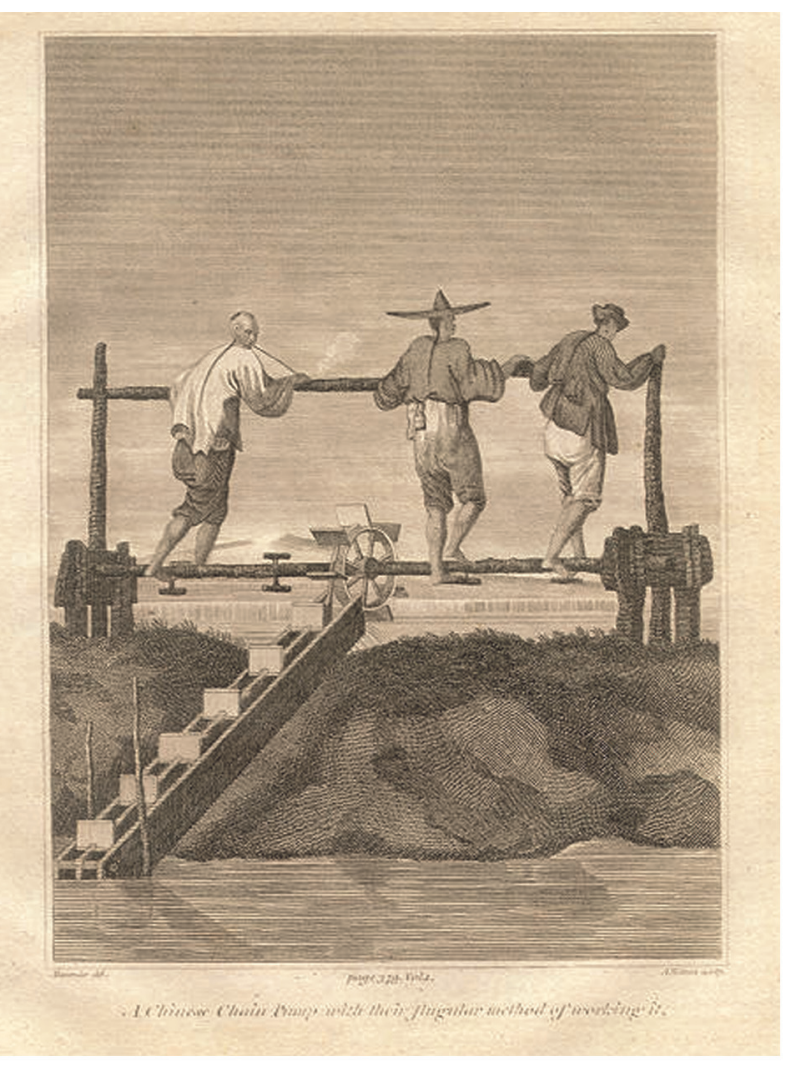

(a)

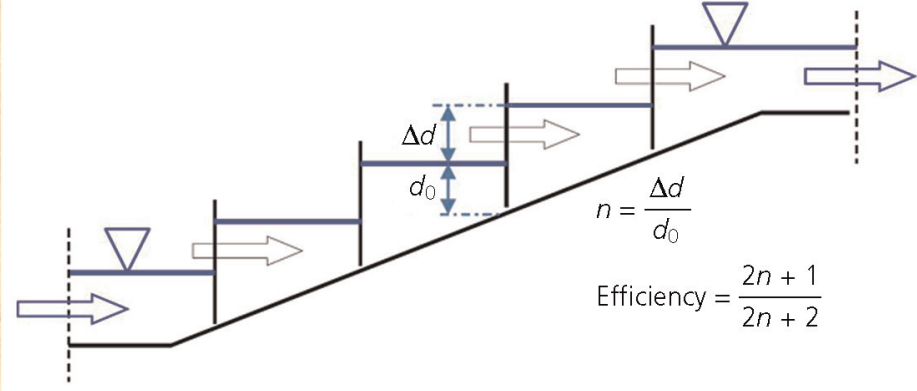

(b)

Figure 11. Chinese chain (or dragon spine) pump. (a) Historic woodprint (Ancestry Images, 1817); (b) principle, pump as turbine

\begin{tabular}{|c|c|c|c|c|c|c|c|}
\hline Type & $\begin{array}{l}H: \\
\mathrm{m}\end{array}$ & $\begin{array}{l}\text { Qesign }^{a} \text { : } \\
\mathrm{m}^{3} / \mathrm{s}\end{array}$ & $\begin{array}{l}P: \\
k W\end{array}$ & $\begin{array}{l}\text { Mechanical } \\
\text { efficiency: \% }\end{array}$ & $\begin{array}{l}\text { Costs: } \\
\mathrm{L} / \mathrm{M} / \mathrm{H}\end{array}$ & $\begin{array}{l}\text { Fish damage: } \\
\mathrm{L} / \mathrm{M} / \mathrm{H}\end{array}$ & $\begin{array}{l}\text { Sediment } \\
\text { passage: Y/N }\end{array}$ \\
\hline Impulse wheels & $0.4-1 \cdot 5$ & $1 \cdot 0-8 \cdot 0$ & $1 \cdot 4-45 \cdot 0^{b}$ & $35-40$ & $\mathrm{~L}$ & M & Y \\
\hline Poncelet wheel & $0.7-1.7$ & $0 \cdot 3-6 \cdot 0$ & $1 \cdot 0-55 \cdot 0^{\mathrm{b}}$ & $55-65$ & M & $\mathrm{H}$ & Y \\
\hline Zuppinger wheel & $0.7-1.5$ & $0.7-6 \cdot 0$ & $5 \cdot 0-60 \cdot 0^{a}$ & $70-75$ & M & $\mathrm{L}$ & Y \\
\hline Francis turbine & $0.75-5.0$ & $1 \cdot 0-10 \cdot 0$ & $10 \cdot 0-200 \cdot 0$ & $75-85$ & M & M & $\mathrm{N}$ \\
\hline Kaplan turbine & $1 \cdot 8-5 \cdot 0$ & $1 \cdot 0-25 \cdot 0$ & $10 \cdot 0-1800 \cdot 0$ & $82-92$ & $\mathrm{H}$ & $\mathrm{H}$ & $\mathrm{N}$ \\
\hline VLH & $1 \cdot 4-3 \cdot 2$ & $10 \cdot 0-30 \cdot 0$ & $100 \cdot 0-500 \cdot 0$ & $80-86$ & $L-M$ & L & $\mathrm{N}$ \\
\hline Archimedes screw & $1 \cdot 0-10 \cdot 0$ & $0 \cdot 1-5 \cdot 5$ & $1 \cdot 0-300 \cdot 0$ & up to 80 & M & L & $\mathrm{N}$ \\
\hline Vortex converter & $0.5-2 \cdot 5$ & $0.5-20.0$ & $1 \cdot 0-200 \cdot 0$ & 41 & M & L & Y \\
\hline HPM & $1 \cdot 0-2 \cdot 5$ & $1 \cdot 0-5 \cdot 0(\approx 20 \cdot 0 ?)$ & $7 \cdot 5-50 \cdot 0(\approx 240 \cdot 0)^{b}$ & $70-82$ & L & $\mathrm{L}$ & Y \\
\hline HPW & $0.2-1 \cdot 0$ & $0.5-10 \cdot 0$ & $1 \cdot 0-75 \cdot 0^{b}$ & $60-90$ & very L & $\mathrm{L}$ & L \\
\hline
\end{tabular}

aDesign flow rate for an energy converter with maximum geometric dimensions

${ }^{\mathrm{b}}$ Assuming a width of $5 \mathrm{~m}$

$\mathrm{H}$, high; HPM, hydrostatic pressure machine; HPW, hydrostatic pressure wheel; L, low; $M$, medium; N, no; Y, yes

Table 1. Comparison of technologies 
about which sufficient information is available. The cost assessment in low (L)/medium (M)/high (H) was done according to machine size and civil engineering works required. The assessment uses the site conditions (head difference $H$ and flow volume $Q$ ) as basis, so that, for example the impulse wheel has low costs for a given site, but also a low efficiency, and its power output and return will therefore be proportionally smaller than the output of a Francis turbine. Fish damage was also assessed as $\mathrm{L} / \mathrm{M} / \mathrm{H}$, using the Kaplan turbine as a reference point while the potential for sediment passage (yes $(\mathrm{Y}) /$ no $(\mathrm{N})$ ) can be judged from the cross-sections of the installations. Table 1 shows the comparison between the different technologies. It immediately becomes obvious that there is no standard solution: the site conditions and requirements will very probably determine the technology to be used. From this point of view, the availability of different technologies is a distinct advantage.

Of the new concepts currently being tested, the HPW is of particular interest because it allows for the utilisation of extremely low head differences down to $0.2 \mathrm{~m}$, whereby the efficiencies of the HPW increase with reducing head differences (or rather with reducing ratios of water depth down and upstream).

The concepts presented in section 3 are also interesting, although the initial idea that modern materials and analysis methods could be used to develop the machines described in the historic engineering literature could not be sustained. The Chinese chain pump has, to our knowledge, as yet not been suggested to be used as an energy converter, although a hydropower machine currently undergoing tests at the University of the German Armed Forces in Munich, the 'Steffturbine' looks somewhat similar (Reist, 2011). Buoyancy devices are now seen mostly as wave energy converters, while the Zuppinger wheel described in section 3.2.1 could be employed, for example in irrigation canals for head drops of 2.5-3 m, where other technologies reach their limits. Both technologies are expected to be environmentally friendly. The value of the historic literature can probably be seen as finding converter technologies for emerging areas of application (wave energy), and/or for the present changed design requirements (environmental compatibility).

GVC are visually attractive, although their space requirement is quite large. Several have been built in the past few years, the efficiencies that were recently experimentally demonstrated are, however, significantly lower than those originally claimed. Technical improvements are under way both at the power take-off and the turbine sides.

The hydrostatic pressure converters described in section 2.4 are currently undergoing full-scale tests. The theoretical concept of HPMs has, however, already been proved to be valuable as it allowed the description of the first ever hydraulic theory of the Archimedes screw (Müller and Senior, 2009), and analyses of other machines such as the Zuppinger wheel theoretically (Schneider et al., 2009).

\subsection{Economy}

Owing to the variability in costs as a function of local conditions, and owing to the lack of cost information it is very difficult to assess the relative costs for different converter technologies at a given site. A recent master's thesis from the University of Architecture, Civil Engineering and Geodesy in Sofia, Bulgaria, compared a Kaplan, Archimedes screw and HPM installation for a site on the River Iskar with a head difference of $2.1 \mathrm{~m}$ and a design flow rate of $5 \mathrm{~m}^{3} / \mathrm{s}$ (Galov, 2011). The detailed analysis of construction costs (here, for simplicity only, the costs for the machine were used as an indicator), maintenance and return, using flow data for a typical year, showed that the HPM has a significant economic advantage. The internal rate of return was determined as $16 \%$ for the HPM, $13 \%$ for the Archimedes screw and $11.5 \%$ for the Kaplan turbine. We assume that the differences in the internal rate of return would have the same trend, but would be considerably larger if costs for civil engineering works were included in the calculation.

\subsection{Practical relevance and potential applications}

The increased interest in low head hydropower in Europe means that design engineers are frequently required to assess potential hydropower sites. Currently, there is, however, no compilation of the available hydropower converter technology available that gives technical details and an engineering comparison to give engineers an overview over available and developing technology, including information about efficiency and areas of application. This paper provides this overview, and gives references where further and more in-depth information can be found, enabling design engineers to make informed choices about suitable technologies for their particular project. The overview also shows the limitations of the technology.

A very promising field of application for low head hydropower is the application in large irrigation systems in countries such as India, Pakistan, the USA, Argentina, etc., where a very large potential with head differences between 0.5 and $3 \mathrm{~m}$ is available. In Pakistan, for example, this potential is estimated to be $5 \mathrm{GW}$ (G. Müller, 2010, personal communication).

\section{Conclusions}

From the review of the engineering literature on hydropower converters for head differences below $2.5 \mathrm{~m}$ the following conclusions could be drawn.

- There are a number of established turbine technologies available. They do, however, suffer from economic disadvantages and from high ecological impacts. A modern development, the VLH turbine, addresses both economic and ecological deficits of traditional turbine technologies. 
- Traditional technologies, such as water wheels, are employed again for sites below $50 \mathrm{~kW}$ and Archimedes screws for up to $300 \mathrm{~kW}$. The Zuppinger wheel, as well as the Archimedes screw working in reverse, have favourable ecological characteristics. Water wheels that rely on impulse exchange, however, suffer from lower efficiencies and may damage fish.

- Several novel technologies are under development and promise improved economic and ecological characteristics for hydropower with VLH differences.

\section{Acknowledgements}

This research has received funding from the European Community's Seventh Framework Programme (FP7/2007-2013) under the grant agreement no. 212423.

\section{REFERENCES}

Ancestry Images (1817) Chinese chain pump for irrigation. www.ancestryimages.com (accessed 08/08/2011).

Bassett DE (1989) A Historical Survey of Low Head Hydropower Generators and Recent Laboratory Based Work at the University of Salford. $\mathrm{PhD}$ Thesis, University of Salford, Salford, UK.

Brada K (1999) Wasserkraftschnecke ermöglicht Stromerzeugung über Kleinkraftwerke [Hydraulic screw generates electricity fvrom micro hydropower stations]. Maschinenmarkt, Würzburg, Mitteilung, 14: 52-56. (http:// www.maschinemarkt.vogel.de/index. $\mathrm{cfm}$ ?pid $=5156 \& \mathrm{pk}=303$ ) (in German).

Collett J (1981) Hydro powered water lifting devices for irrigation. Proceedings of the FAO/DANIDA Workshop on Water Lifting Devices in Asia and the Near East, Bangkok, Thailand. December 1979, FAO, Rome, Italy.

ETSU (Energy Technology Support Unit) (1989) The AUR water engine. Report ETSU-SSH-4065. ETSU, Harwell, UK.

Fishtek (2007) Fish monitoring and live fish trails. Archimedes screw turbine, River Dart. Phase 1 report: Live fish trails, smolts, leading edge assessment, disorientation study, outflow monitoring. Report for Mann Power Consulting Ltd. Fishtek Ltd., Moretonhampstead, UK.

Fishtek (2008) Archimedes screw turbine fisheries assessment. Phase II: Eels and kelts. On behalf of Mann Power Consulting Ltd. Fishtek Ltd., Moretonhampstead, UK.

Fraser R, Deschênes C, O'Neil C and Leclerc M (2007) VLH: Development of a new turbine for very low head sites. Proceedings of Waterpower XV, Chattanooga/Tennessee, Paper 157.

Galov M (2011) Comparative Design of a Very Low Head Run-of-River SHPP on Iskar River for Different Types of Hydromechanical Equipment. Diploma thesis, University of Architecture, Civil Engineering and Geodesy, Sofia, Bulgaria (in Bulgarian).
Gerhardt P (1893) Über Aalleitern und Aalpässe. Zeitschrift für Fischerei und deren Hilfswissenschaften 1: 194-199 (in German).

Giesecke J and Jorde K (1999) Technical and ecological overall concepts for the reactivation, modernization and relicensing of hydropower plants. Proceedings of the 28th IAHR Congress, Graz, Austria (on CD).

Giesecke J and Mosonyi E (2009) Wasserkraftanlagen. Planung, Bau und Betrieb. 5. aktualisierte und erweiterte Auflage. Springer-Verlag, Berlin, Heidelberg, Germany (in German).

Graf O (1906) Theorie, Berechnung und Konstruktion der Wasserturbinen und deren Regulatoren. 3. Aufl., August Lachner, München, Germany (in German).

Hahn C (2006) Weltneuheit "Gravitationswasserwirbelkraftwerk". Aqua Press International Water Technology 1(1): 16-17 (in German).

Hellmann DH (2003) Gutachten zur Wirkungsgradbestimmung an einer Wasserkraftschnecke Fabrikat Ritz-Atro. Report TU Kaiserslautern Fachbereich Maschinenbau und Verfahrenstechnik. Kaiserslautern, Germany (in German). Lashofer A, Kaltenberger F and Pelikan B (2011) Wie gut bewährt sich die Wasserkraftschnecke in der Praxis? Wasserwirtschaft 101(7-8): 76-81 (in German).

Leclerc M (2010) The very low head turbine confirms its extremely low environmental impact and enters into industrial phase. Proceedings of Hidroenergia 2010, paper 3B-07. http://2010.hidroenergia.eu/publications_en.php (accessed 10/12/2012).

Ludin A (1913) Die Wasserkräfte: ihr Ausbau und ihre wirtschaftliche Ausnutzung; ein technisch-wirtschaftliches Lehr- und Handbuch. Parts 1 and 2. Springer Verlag, Berlin, Germany (in German).

MJ2 Technologies (2011) VLH - Very low head turbine. http://www.vlh-turbine.com (accessed 23/07/2011).

Müller G and Senior J (2009) Simplified theory of Archimedean screws. Journal of Hydraulic Research 47(5): 666-669.

Müller G, Denchfield S, Marth R and Shelmerdine R (2007) Stream wheels for applications in shallow and deep water. Proceedings of 32nd IAHR Congress, Venice, Italy, Theme C2c, paper 291.

Müller G, Bruce B, Stagonas D and Jenkins R (2010) A nonresonant, buoyancy-type wave energy converter. Proceedings of ICOE 2010, Barcelona, Spain.

Müller W (1899) Die eisernen Wasserräder, Erster Teil: Die Zellenräder, Zweiter Teil: Die Schaufelräder, Atlas [The iron water wheels, Part 1: the cell wheels, Part 2: the paddle wheels, Technical Drawings]. Veit \& Comp., Leipzig, Germany (in German).

Ossberger (2011) Kaplanturbinen - Turbinen im Niederdruckbereich. http://www.ossberger.de/cms/hydro/ kaplan-turbine/prospekt/ (accessed 01/08/2011) (in German). 
Poncelet JV (1827) Mémoire sur les roues hydrauliques à aubes courbes mues par-dessous - Second mémoire sur des expériences, en grand, relatives aux roues à aubes courbes, mues pardessus, contenant des observations sur la théorie de ces roues, et uns instruction pratique sur la manière de procéder à leur établissement. Librarie M.V. Thiel, Metz, France (in French).

Rauch A (1959) Wasserkraftanlagen. Frankh Verlag, Stuttgart. Germany (in German).

Reist W (2011) Steffturbine - linear power. www.steffturbine. com/ (accessed 11/10/2012) (in German).

Schnedermann GHE and Böttcher ET (1855) Das Zuppinger'sche Wasserrad. In Polytechnisches Zentralblatt pp. 972-976 (in German).

Schneider S, Saenger N and Müller G (2009) Untersuchungen zur Optimierung eines Wasserrades. Wasserbaukolloqium TU Dresden pp. 379-388 (in German).

Senior J, Saenger N and Müller G (2010) New hydropower converters for very low head differences. Journal of Hydraulic Research 48(6): 703-714.
Späh H (2001) Fischereibiologisches Gutachten zur Fischverträglichkeit der Patent geschützten Wasserkraftschnecke der RITZ-ATRO GmbH. Study on behalf of RITZ-ATRO Pumpenwerksbau GmbH, Nürnberg, Germany (in German).

Urbani C (2011) Wasserwirbelkraftwerk. Bachelor thesis, Fachhochschule Nordwestschweiz. http://web.fhnw.ch/ technik/projekte/eit/Herbst2010/CerGaf/ergebnisse.html (accesssed 01/08/2011) (in German).

Walter Reist Holding (2011) Steffturbine - linear power. http://www.unibw.de/bauv6/HYDRO/projekte/steffturbine (accessed 01/08/2011) (in German).

Weisbach J (1883) Die Statik der Bauwerke und die Mechanik der Umtriebsmaschinen, Zweiter Teil, Ingenieur- und Maschinenmechanik. Zweite Abteilung Die Mechanik der Umtriebsmaschinen. 5. Auflage, Vieweg \& Sohn, Braunschweig, Germany (in German).

Zotlöterer F (2010) Wasserwirbelkraftwerk. www.zotloeterer. com (accessed 25/07/2011) (in German).

\section{WHAT DO YOU THINK?}

To discuss this paper, please email up to 500 words to the editor at journals@ice.org.uk. Your contribution will be forwarded to the author(s) for a reply and, if considered appropriate by the editorial panel, will be published as a discussion in a future issue of the journal.

Proceedings journals rely entirely on contributions sent in by civil engineering professionals, academics and students. Papers should be $2000-5000$ words long (briefing papers should be 1000-2000 words long), with adequate illustrations and references. You can submit your paper online via www.icevirtuallibrary.com/content/journals, where you will also find detailed author guidelines. 